\title{
Mechanisms to promote board gender diversity in South Africa
}

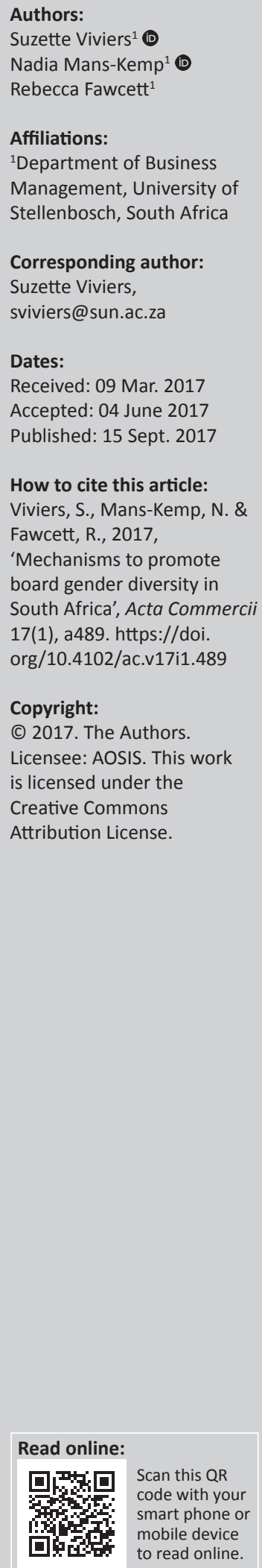

Research purpose: Board gender diversity is gaining increasing attention globally and in South Africa. Although more women are serving on the boards of companies listed on the Johannesburg Stock Exchange (JSE), they only represent approximately one-fifth of all directors. This situation mirrors international trends. A review of the extant literature revealed three prominent mechanisms to increase the appointment of female directors, namely mandatory board gender quotas, voluntary targets and shareholder activism. The authors critically evaluated these three mechanisms with the aim of suggesting the most appropriate ones in the South African context.

Motivation for the study: The study was undertaken given the paucity of comparative research on the three change mechanisms and the need to promote greater board gender diversity in South Africa.

Research design: Judgement and snowball sampling were used to identify a sample of experienced local asset managers. Semi-structured personal interviews were conducted to gauge these individuals' views on the applicability of these change mechanisms in South Africa. The qualitative data were analysed using thematic analysis.

Key findings: Although the participants acknowledged the importance of board gender female board representation, none of them have engaged investee companies on the topic over the period 2011-2016. This study provides evidence that legislation is the least preferred mechanism to promote board gender diversity in South Africa. Voluntary targets and public pressure from shareholders might be more effective.

Contribution: Whereas existing research mainly centres on the rationale for board gender diversity, this study goes a step further by investigating three prominent mechanisms to promote female board representation. A contribution is made to the body of knowledge on diversity management. Context-specific recommendations are offered.

\section{Introduction}

'Freedom cannot be achieved unless women have been emancipated from all forms of oppression.' (Nelson Mandela, Opening of parliament 1994, in Kelly 2013)

In his fight for freedom, Mandela devoted himself to the empowerment of women (Kelly 2013). The 1996 constitution grants South African women one of the most comprehensive sets of rights globally. Various laws, which have their roots in the constitution, were promulgated to redress the disadvantages experienced by women, Black people and individuals with disabilities during the apartheid regime (Liebenberg 2000). A Commission for Gender Equality (2017) was furthermore established in 1996 to evaluate the extent to which government and private sector policies promote gender equality. The Commission also reviews applicable legislation, makes recommendations to parliament and investigates gender discrimination complaints. Parliamentarians have an important role to play in empowering women across the economic spectrum. Evidence from the 2016 municipal elections, however, shows that gender equality does not enjoy the same status that it had during Mandela's presidency. There are also fewer visible champions for women's rights in government at present (Vetten 2016).

Historic gender biases hinder the equitable use of the talent pool in several countries (Seierstad, Huse \& Seres 2015). According to Ernst and Young (2014), women are under-represented in leadership positions in many of the G20 countries. Furthermore, female board membership for the 200 largest companies globally was reported to be a mere 17.3\% (African Development Bank 2015). The Governance Metrics International (GMI) Ratings 2013 Women on Boards survey 
revealed that South Africa ranked fifth globally in terms of board gender diversity (Natesan 2013). The GMI Ratings (2014) database contains environmental, social and corporate governance research and ratings for more than 6000 firms globally. Despite this seemingly reasonable ranking, females only held approximately one-fifth of all local board positions in 2015 (BWA 2015).

Apart from historic gender biases, a number of other reasons contribute to the relatively low levels of female board representation. Some authors mention a lack of support for women in a traditionally male-oriented corporate environment, noting that women are not always welcomed as professional equals (Cha 2013; Chovwen 2007; Martin \& Barnard 2013). Child rearing responsibilities furthermore hamper women from reaching the highest corporate echelons (Davies 2011; Marthur-Helm 2005). Other scholars note that nomination committees mainly source board candidates from the so-called 'Old Boys' Club' (Kumra \& Vinnicombe 2008; Perrault 2015) resulting in the nomination (and eventual election) of homogenous directorates. Given the historically low number of female board members, there are very few role models who can mentor younger female contenders.

The scholarly debate on board gender diversity was initially based on why women should be appointed as directors. The balance of evidence shows that board gender diversity is positively associated with social legitimacy and economic efficiency (Marquardt \& Wiedman 2016). There is hence growing pressure on governments and public companies to deal with the under-representation of women in senior positions (Seierstad \& Opsahl 2011). The debate has consequently shifted to how board gender diversity could be enhanced (Willey 2017).

Three prominent mechanisms to increase female board representation were identified in the literature, the first being mandatory board gender quotas. In 2003, Norway took the lead by legislating a $40 \%$ quota. Only $9 \%$ of directors of public Norwegian companies were women at that time (Ahern \& Dittmar 2012). Not all women welcomed this quota, arguing that they wanted to be appointed on merit, not on the basis of gender (Wiersema \& Mors 2016).

A second mechanism, voluntary board gender targets, offers an alternative to legislation. The UK implemented a voluntary target in 2011 and has since seen significant changes in the gender composition of listed companies (Davies 2011). Shareholder activism represents a third mechanism. Institutional investors and other shareholder activists could play a central role in promoting female representation at the highest corporate echelons (Marquardt \& Wiedman 2016). Shareholder activists are investors who use their equity stake in a company to influence corporate policies, practices and outcomes (Partnoy \& Thomas 2005).

Several scholars (including Ahern \& Dittmar 2012; Bertrand et al. 2014; Bøhren \& Staubo 2014; Sorsa 2016; Terjesen,
Aguilera \& Lorenz 2015) examined the outcomes of board gender quotas, especially in Norway. Although they agreed that the pool of female directors increased as a result of such legislation, limited progress was noted in listed companies after the quota was reached (Wang \& Kelan 2013). In addition, Seierstadt and Opsahl (2011) warned that a small group of 'elite' women obtained excessive power in some instances.

An extensive literature review revealed that, although previous authors explored the advantages and shortcomings of board gender targets (Du Plessis, O'Sullivan \& Rentschler 2014) and reported improvements in female board representation (Clarke 2017), the effectiveness of this change mechanism has not received the same academic attention as legislated quotas. A possible reason is that several countries only recently introduced voluntary board gender targets. Longitudinal studies on the effectiveness thereof are hence expected in future. With the exception of Marquardt and Wiedman (2016) and Perrault (2015), very limited research has been conducted on the effectiveness of shareholder activism to change the gender composition of boards.

Given the paucity of comparative research on the three mechanisms and the need to promote greater board gender diversity in South Africa, the authors set out to critically evaluate these three mechanisms. The purpose of the study was furthermore to propose the most suitable means to promote female board representation in the country. Semistructured personal interviews were conducted with local shareholder activists to gauge their views on the applicability of the three change mechanisms in South Africa. The findings of this study contribute to the body of knowledge on diversity management.

The discussion in the following sections will centre on the benefits that women can bring to boardrooms, possible reasons for the low level of female board representation and a comparison of the three change mechanisms. An overview of the research design and methodology will then be presented followed by the empirical findings, pertinent conclusions and recommendations.

\section{Benefits, concerns and possible reasons for the low level of female board representation}

Board gender diversity is a controversial topic. There are several arguments for and against the appointment of female directors. Arguments for enhanced female board representation range from a moral imperative claiming that it is the 'right thing to do' (Robinson \& Dechant 1997) to reasoning that it is the 'bright thing to do' (Terjesen, Sealy \& Singh 2009). The former claim centres on the notions of social justice, fairness and equality, while the latter is based on the strategic and financial benefits of board gender diversity (Farrell \& Hersch 2005; Seierstad 2016). 
Previous authors ascertained that female directors often bring new perspectives and offer alternative solutions for complex problems (Bart \& McQueen 2013; Torchia, Calabrò \& Huse 2011). Female leaders also tend to have a more collaborative leadership style than men (Konrad, Kramer \& Erkut 2008). They are therefore more open to diverse opinions, more willing to ask controversial questions and less likely to resort to 'group thinking' (Natesan 2013). Females are furthermore inclined to support open internal communication channels where everyone's voice can be heard. A constructive atmosphere for sharing ideas and knowledge is thus created, which in turn could result in more innovative decision-making (Ritter-Hayashi, Vermeulen \& Knoben 2016).

Gul, Hutchinson and Lai (2013) found that gender diverse boards reported financial performance in a more transparent and accurate manner than male-dominated boards. A positive business case for board gender diversity (also referred to as the utility argument) was observed by several authors (Adams \& Ferreira 2009; Seierstad 2016; Simpson, Carter \& D'Souza 2010). In addition to financial benefits, gender diverse boards are associated with proactive social and environmental policies, practices and reporting (Bernardi \& Threadgill 2010; Glass, Cook \& Ingersoll 2015). Bear, Rahman and Post (2010) reported a positive association between board gender diversity and a company's reputation as a good corporate citizen.

Given that women are responsible for the majority of consumer spending, they often have an intimate knowledge of product markets and tend to be more responsive to customers' needs than their male counterparts (Simpson et al. 2010). In addition, Perrault (2015) argued that the presence of female directors enhances public perceptions of the board's legitimacy and trustworthiness. Gender diverse boards also tend to be more diligent in monitoring management than homogenous ones (Adams \& Ferreira 2009).

Although it is possible for one female director to bring about change on her own, significant changes generally only occur once a critical mass of three or more female directors have been appointed to a board (Konrad et al. 2008). In contrast to the benefits, adverse consequences of female board representation have also been observed in the literature. Raising diverse opinions at board level might result in conflict, slower decision-making and in some cases weaker financial results (Adams \& Ferreira 2009). It should be noted that the discussed benefits and disadvantages of board gender diversity are applicable in developed and emerging markets.

There are various reasons why women are still underrepresented at board level. The claim is often made that the pool of eligible female candidates is too small (Tinsley et al. 2017). This argument is very apt in the South African context given that only about $12 \%$ of all female matriculants qualify for university acceptance (Steward 2014). In addition, almost half of all students who commence a degree never graduate (Mdaka 2016).
Gender stereotyping, the so-called 'glass ceiling' and the prevalence of 'queen bees' might also hinder women's progress in climbing the corporate ladder (Davies 2011; Johnson \& Mathur-Helm 2011; Torchia et al. 2011). 'Queen bees' refer to women who made it to the top, but who are reluctant to assist other women to do the same (Mavin 2008). When contemplating a healthy work-life balance, women often experience conflict in deciding which career goals to pursue and feel anxious about the sacrifices required to reach a senior position (April, Dreyer \& Blass 2007; Gino \& Brooks 2015). Some women therefore make a conscious decision not to pursue directorships.

Whereas the focus of the preceding discussion was on the rationale for board gender diversity, attention will now shift to three prominent mechanisms to address gender imbalances at board level. The international perspective will be discussed first, followed by a number of South African initiatives.

\section{Change mechanisms: An international perspective Mandatory board gender quotas}

Quotas obligate listed companies to appoint a specific percentage of female directors by a given date. Noncompliance could result in fines or even suspension from certain stock exchanges (OECD 2012). As mentioned earlier, Norway introduced a $40 \%$ mandatory board gender quota in 2003 (Ahern \& Dittmar 2012). Companies initially resisted the idea, arguing that it would be difficult to find suitably qualified female candidates and that the quota was an 'unnecessary interference in business' (Bertrand et al. 2014). Ahern and Dittmar (2012) reported that share prices decreased substantially when the law was announced. In addition, business performance deteriorated in the months that followed. They also noted that some directorates comprised younger and less experienced members after the law was implemented.

Opponents of mandatory quotas warn that gender quotas might result in token appointments and overboarded directors (Davies 2011; Wiersema \& Mors 2016). A female director could be regarded as a token appointment if she is elected purely for diversity purposes and not for her experience and qualifications (Nyirenda 2010). Directors could become overboarded when they serve on several boards simultaneously. Evidence shows that such directors often exhibit poor meeting preparation and attendance (Harris \& Shimizu 2004). Questions regarding their independence and impartiality could also be raised (Ensor 2014).

In the Norwegian context, Wang and Kelan (2013) moreover established that the gender gap in companies did not improve after the $40 \%$ quota has been reached. Bertrand et al. (2014) furthermore observed that the reform had very little discernible impact on women in business beyond its direct effect on board composition. Some firms even delisted, 
arguing that forced gender equity is too costly (Bøhren \& Staubo 2014).

Those who are in favour of legislation claim that the natural progression of women to top corporate structures is too slow and that quotas could rapidly address the status quo. Proponents also argued that quotas could contribute to more formal and professional director nomination processes (Sorsa 2016; Wiersema \& Mors 2016).

Although initially debated (Bertrand et al. 2014; Terjesen \& Sealy 2016), mandatory board gender quotas have since been successfully implemented in Norway (Seierstad 2016). Several other European countries, such as Spain, France and Belgium, subsequently followed Norway's example (Catalyst 2014). In 2012, the European Commission proposed a directive to improve board gender diversity all over Europe. The Commission suggested a binding measure stipulating that $40 \%$ of all non-executive directors should be female by 2020 (European Parliament News 2015). The proposal has not yet been accepted by the European Council.

Some critics of gender-based legislation contend that gender diversity should rather be encouraged through 'softer' reforms such as voluntary targets (Seierstad 2016).

\section{Voluntary board gender targets}

A voluntary target of $25 \%$ female board representation by 2015 was introduced for FTSE 100 companies in 2011 (Davies 2011). As the initial target was reached, a new target of $33 \%$ was introduced for FTSE 350 companies by 2020 (Davies 2015). To support listed companies in reaching the new target, an independent steering body was appointed. This body monitors and periodically reports on companies' progress. Additional initiatives have since been introduced in the UK to develop and support women in senior management positions. These include the possibility to request flexible working hours, parental leave and the provision of childcare facilities (Davies 2015).

Arguments in support of voluntary targets include that they can be gradually adopted, hence encouraging positive commitment rather than enforcing compliance (Clarke 2017). Companies could thus develop diverse board candidates over time. However, given their voluntary nature, board gender targets might be set, but never reached. As Clarke (2017) aptly remarks, other objectives might be regarded as more important than the voluntary appointment of female directors.

In 2015, the Australian Institute of Company Directors (2016) introduced a quota of $30 \%$ female directorships for Australian Securities Exchange 200 companies by 2018. At the end of 2016 , female directors accounted for $25 \%$ of board positions in comparison to $8.3 \%$ in 2009 .

\section{Shareholder activism on board gender diversity}

Shareholders have the ability to change the gender composition of a board by using exit or voice strategies. In an exit strategy, shareholders 'vote with their feet' by selling some or all their shares in a particular company. If a large number of shareholders divest simultaneously, the targeted company's market valuation and cost of capital could be adversely affected (Gillan \& Starks 2003).

In a voice strategy, shareholders engage directors and managers formally or informally on issues of concern (Goodman et al. 2014). Formal voice strategies include efforts that are made publicly, such as the filing of shareholder resolutions, voting, questioning management at annual general meetings (AGMs) and stimulating public debate via traditional and social media. In contrast, informal activism occurs behind the scenes and typically involves confidential negotiations between shareholders, managers and directors (McCahery, Sautner \& Starks 2016; Nordén \& Strand 2011).

Shareholders can promote board gender diversity in a number of ways: firstly, by voting in favour of the appointment or re-appointment of female nominees, secondly, by filing shareholder resolutions in which they propose their own female candidates and thirdly, by engaging in private with nomination committees on the eligibility of certain candidates. A growing number of academic studies mention board gender diversity as an important shareholder engagement topic (Bauer, Moers \& Viehs 2015; Loop 2016; Rehbein, Waddock \& Graves 2006).

The choice of engagement strategy is largely determined by the size of the shareholder and the level of investor protection in a country. Given that institutional investors (pension funds and insurance companies) typically have large shareholdings, they have more voting and negotiation powers compared to smaller investors (Almazan, Hartzell \& Starks 2005). The latter seldom have the opportunity to access management directly and are subsequently limited to voicing their discontent through public voice strategies (Willard et al. 2002).

Research shows that institutional investors in common law countries, notably the UK, generally enjoy strong investor protection (La Porta et al. 2000). As such, they prefer private engagements to public campaigns (Becht et al. 2010).

The role that shareholders can play in promoting board gender diversity in the UK was emphasised in the 2011 Davies report. Shareholders were urged to give more attention to board appointment processes, companies' plans to enhance female board representation and corporate reporting in this regard (Davies 2011).

As there are currently no mandatory board gender quotas or voluntary targets in the USA, institutional investors have an even greater responsibility to drive the gender diversity agenda. In contrast to the UK, investors in this 
civil law country prefer public voice strategies, particularly the filing of shareholder resolutions and voting, to private voice strategies (Kamonjoh 2014). Willard et al. (2002) found that several companies that were targeted by a large US pension fund nominated female board candidates postengagement. Perrault (2015:162) also determined that some US shareholders have been effective in 'de-institutionalising homophilous boards and re-institutionalising gender diverse boards'. Many directors and activists in Perrault's (2015) study opposed board gender quotas.

Marquardt and Wiedman (2016) reported a negative relationship between female board representation and the likelihood of being targeted. They investigated genderrelated shareholder proposals for selected S\&P 1500 firms over the period 1997 and 2011. Because targeted companies appointed considerably more female directors in the one-year period following the shareholder proposal (in comparison to non-targeted firms), these authors argued that shareholder activism was an effective mechanism to enhance female board representation. Increasing numbers of US shareholders are also joining a campaign called the 'Thirty Percent Coalition' (2017) calling for a progressive target of 30\% female directors serving on the boards of listed companies.

Given the growing influence of shareholders, it could be argued that the corporate governance environment is moving from a 'board-centric' model to an 'investor-centric model' (PwC 2016).

\section{Change mechanisms: A South African perspective}

A number of initiatives to promote board gender diversity in South Africa were introduced since the late 1990s. The following discussion will present these initiatives in chronological order.

\section{Voluntary government initiatives}

South Africa was one of 189 countries that endorsed the millennium development goals formulated by the United Nations in 2000. A number of targets, which were to be met by 31 December 2015, were conceived to promote gender equality and female empowerment. These targets included equal enrolment in primary, secondary and tertiary institutions, equal levels of literacy across genders and equal employment opportunities. Whereas government met the first two targets, it fell short on the third one (Oliphant 2015).

Along with other heads of state, the South African president signed the Southern African Development Community's (SADC) Protocol on Gender and Development in August 2008. Signatories of this Protocol were expected to meet 23 progressive targets by the end of 2015. One of these targets was the appointment of women in $50 \%$ of decision-making positions in both public and private sector organisations (Chamuka 2011). Although female representation in senior decision-making positions in the public sector increased substantially post 1994, it was still well below the target in 2015 (Mabe 2015). The same situation was noted for listed companies (Mans-Kemp \& Viviers 2015). Given the slow progress against these voluntary targets, an attempt was made to legislate board gender diversity in the country.

\section{Board diversity legislation}

In November 2013, the National Women Empowerment and Gender Equity Bill was tabled in parliament. In line with the SADC's targets, the progressive appointment of at least $50 \%$ females in corporate decision-making structures was proposed. This quota was criticised as being unrealistic and unattainable (Ensor 2014). Critics argued that government should rather address the fundamental problems that underlie gender inequality in the country (such as a crumbling education system and rigid labour policies) than impose a legislative quota (Steward 2014).

Concerned parties claimed that the Bill would place an additional administrative burden on companies, might contribute to tokenism and overboardedness and had 'vague' objectives and weak enforcement mechanisms (BWA 2013; Scholtz 2014; Steward 2014). The Bill was consequently withdrawn (Department of Women, Children and People with Disabilities 2015).

Given South Africa's unique sociopolitical history, the promotion of race and gender diversity are closely related. One of the participants in a countrywide study acknowledged this intersection by stating that she is not a woman on some days and a Black individual on other days, but both at the same time (Fajardo \& Erasmus 2017). Although there is currently no board gender diversity legislation in the country, the Broad-Based Black Economic Empowerment (B-BBEE) Act and its accompanying Codes of Good Practice partly promote the participation of Black women in corporate decisionmaking.

According to the 2013 B-BBEE Codes of Good Practice, a company's level of B-BBEE compliance is determined by five metrics, namely ownership, management control, skills development, enterprise and supplier development and socioeconomic development. Pertinent reference is made to the appointment of female leaders in the second and third metrics. A $25 \%$ compliance target was set for the exercisable voting rights of Black female directors (as a percentage of all directors) and for Black female executives (as a percentage of all executives). Compliance targets were also set for Black female employees in senior, middle and junior management. Johannesburg Stock Exchange (JSE)-listed companies are expected to report on their B-BBEE compliance on an annual basis (Department of Trade and Industry 2013).

\section{Shareholder activism on board gender diversity}

Although more muted than in the UK and USA, a steady increase in shareholder activism has been observed in South Africa (Bonorchis 2016; Deloitte 2015; Hasenfuss 2016). 
Being a common law country, a strong preference for private engagements exists (Yamahaki \& Frynas 2016). Given the opaque nature of these engagements, it is unclear to what extent the topic of board gender diversity is being raised with local investee companies. Studies on proxy voting (Viviers \& Smit 2015) and public criticism of JSE-listed companies by a prominent individual shareholder activist (Bhana 2010) do not shed light on the matter either.

\section{Other initiatives}

To discharge its roles and responsibilities objectively and effectively, the King IV report on corporate governance recommends that a directorate should comprise 'an appropriate balance of knowledge, skills, experience, diversity and independence'. Although directorates are advised to set ethnic and gender diversity targets and to report on their progress, no formal targets are proposed (IoDSA 2016a).

As from 1 January 2017, all JSE-listed companies are required to have a formal policy on board gender diversity and to disclose their progress on an annual basis (JSE 2015). The JSE also added a disclosure item on board ethnic diversity to their listing requirements in November 2016. The effective implementation date for the latter has not yet been announced (JSE 2016).

An initiative similar to the Thirty Percent Coalition in the USA, the 30\% Club, was introduced in the UK in 2010. This Club, which has been active in South Africa since 2014, seeks to harness the influence of business leaders to prioritise gender diversity at board level. The 30\% Club enjoys the support of the Institute of Directors in Southern Africa (IoDSA 2016b).

\section{Research design and methodology}

Given the growing importance of institutional investors as change agents, asset managers were approached to participate in this study. Judgement and snowball sampling techniques were used to identify suitable participants. All interviewees had to have experience as active owners (albeit on behalf of their clients, the asset owners).

All interviewees had been involved in the asset management industry for an extensive period of time, the least being 8 years and the maximum being 27 years. Five of the eight participants were male. All participants have engaged investee companies in the past 5 years. Semi-structured personal interviews were conducted until data saturation occurred. Eight interviews were conducted in Cape Town and Johannesburg during July and August 2016.

An interview guide was compiled comprising four sections. In Section A, the biographic information of the participants and their employers was requested. Insight into the size of the assets under management was deemed important, as prior research has indicated that size has a significant influence on an asset manager's choice of voice strategy or strategies.
Section B comprised open-ended questions to determine participants' views on the importance of board gender diversity in South Africa, mandatory board gender quotas and voluntary targets. The extent to which participants engaged investee companies on issues of concern (including board diversity) was assessed in Section C. Lastly, participants were given the opportunity to suggest other ways of improving female board representation in the country.

All interviews were recorded and transcribed by a professional transcriber. The qualitative data were then analysed by using thematic analysis. To counteract possible researcher subjectivity, care was taken to present a balanced view of the three change mechanisms. Attention was also given to the principles of credibility, transferability, dependability, conformability and research ethics.

\section{Empirical results}

\section{Participants' views on the importance of board gender diversity in South Africa}

Whereas a number of interviewees had never even thought about board gender diversity, others considered it to be a very important topic. One participant commented that although board diversity was often raised in discussions, it only centred on ethnic diversity 'probably because it is legislated in South Africa'. Another asset manager was of the opinion that it was only a matter of time before board gender diversity would receive the same level of 'attention and concerted effort' locally as has been the case globally.

\section{Participants' views on board gender diversity legislation and targets}

All eight interviewees were opposed to mandatory board gender quotas. Some argued that it would not be in the best interest of companies to appoint female directors simply because they are obligated to do so. Concerns about the possibility of token appointments and director overboardedness that could result from mandatory quotas (Davies 2011; Harris \& Shimizu 2004; Wiersema \& Mors 2016) were also mentioned. One interviewee stated that quotas would create more demand for an already scarce and expensive talent pool. This interviewee continued by saying that small companies in particular might find it difficult to attract eligible female candidates. 'As a result, they might attempt to find loopholes in the legislation which will counteract the objective of the law'.

General consensus existed among the participants that sufficient legislation (notably the B-BBEE Act) and normative codes are already in place in South Africa to enhance board gender diversity. They added that 'there just needs to be a greater will to implement what's already there ... legislation should always be the last resort'. Most of the sampled asset managers indicated that the negative implications of mandatory board gender quotas were likely to outweigh the positive ones. The findings corroborate existing research on quotas highlighted in the literature review. 
Participants were more favourably disposed towards progressive voluntary targets to increase female board representation.

\section{The nature and extent of engagements with investee companies}

All eight participants increased their engagement activities over the research period (2011 to 2016). One asset manager mentioned that they relied on other shareholders to change corporate structures. This asset manager only stepped in when they thought that an investee company was behaving unethically. This attitude is typical of the so-called 'free riders' who know that active shareholders only realise a relatively small fraction of the engagement benefits while bearing the full cost thereof (McCahery et al. 2016; Rao, Morril \& Zald 2000).

None of the interviewees used an exit strategy, mainly because of the limited number of companies listed on the JSE. Interviewees were split according to their preferred voice strategy. Three participants were completely opposed to the use of public voice strategies. They argued that 'airing dirty laundry in public' was the least effective way of initiating change: 'There is a limited number of good local companies to invest in. Therefore, maintaining healthy relationships is critical'. Other asset managers asserted that 'a lot more can be done behind the scenes' and that 'one-on-one discussions are more constructive [than speaking out in public]'. They felt that private negotiations gave them the opportunity to exert pressure on investee companies without damaging the companies' reputations.

Those participants who favoured a public voice strategy claimed that issues raised in public 'could no longer be swept under the carpet' by the targeted companies. One interviewee said that private activism 'can leave many stones unturned' and that this strategy was quite slow in bringing about organisational change. In contrast, public criticism resulted in much quicker and more satisfactory responses from investee companies.

As suggested in the literature (Almazan et al. 2005), the choice of voice strategy was primarily driven by the size of the assets managed. As expected, large asset managers in this study mostly voiced their concerns during confidential meetings, whereas smaller asset managers resorted to public voice strategies. Accessing management was a major obstacle for most of the interviewees: '[Even as] one of the biggest shareholders in South Africa, it sometimes takes us a year or two to actually get a meeting with a member of the board'. One of the smaller asset managers mentioned that they started their engagement process by writing letters to targeted companies prior to their AGMs. Despite explaining their opposition to particular resolutions in these letters, they were never invited to discuss their concerns with managers or directors. These findings are in line with previous shareholder activism studies that have been conducted in South Africa, notably Yamahaki and Frynas (2016) and Viviers and Smit (2015).
The nature of asset managers' concerns also influenced the choice between public and private engagement. One participant remarked that engagements on company-specific issues, such as board composition, mostly took place in private, whereas industry-specific concerns, such as pollution, were generally raised in public.

'Although the public is not encouraged to 'gang up' against a specific company, issues of public interest should be discussed openly. Opinions raised in public can have a powerful ripple effect throughout an industry, which can result in pressure to change.'

None of the sampled asset managers has directly engaged investee companies on board gender diversity between 2011 and 2016. Participants explained that board gender diversity 'sits at the bottom of the [engagement] priority hierarchy' and that they deemed concerns about financial performance and ethnic diversity to be more important. This finding is in line with Gantchev (2013) who found that most shareholder activists engage companies on financial rather than social concerns.

\section{Other suggestions to promote board gender diversity in South Africa}

Participants felt that South African companies should do more to identify and respond to employees' needs (both male and female) in terms of a healthy work-life balance and their aspirations to climb the corporate ladder. The interviewees recommended that companies offer more training and mentoring opportunities to potential board candidates (both male and female) as 'good quality directors are in short supply'.

Participants suggested that women should acquire the necessary skills to 'handle themselves in a male-dominated environment'. One interviewee remarked that even if women are successful in reaching the boardroom, they continue to face an uphill battle to 'remain in the loop'. Training and mentorship programmes should therefore not only hone women's leadership skills, but should also give them the tools to cope with the proverbial 'Old Boys' Club'. The need for cultural change was furthermore highlighted. Participants suggested that deep-rooted, traditional gender stereotypes need to be addressed urgently. The latter suggestion also features prominently in literature (Fajardo \& Erasmus 2017).

\section{Summary, conclusions and recommendations}

Board gender diversity is gaining increasing attention both globally and in South Africa. Although more women are serving on the boards of JSE-listed companies, they still represent only about one-fifth of all directors. This situation mirrors international trends. Whereas prior studies centred on the rationale for having gender diverse boards, the academic debate now centres on mechanisms which could address gender imbalances at board level. Prominent 
mechanisms include mandatory board gender quotas, voluntary targets and shareholder activism.

Given the paucity of comparative research on the three change mechanisms and the need to promote greater board gender diversity in South Africa, the authors set out to critically evaluate these mechanisms. In addition to a comprehensive review of these mechanisms, semi-structured personal interviews were conducted with eight experienced, local asset managers of both genders.

Although participants acknowledged the importance of board gender diversity in South Africa, none of them supported mandatory quotas. The authors agree with the research participants that additional legislation is not the best option to enhance female board representation in South Africa. The reason being that B-BBEE legislation already contributes, in part, to more Black women being appointed to the boards of JSE-listed companies.

The authors share the interviewees' and international scholars' concerns about legislative quotas, namely the shortage of competent female board candidates, potential tokenism, director overboardedness, limited impact on women in lower and middle management and the search for potential loopholes.

Interviewees were more favourably disposed towards voluntary targets to enhance female board representation in South Africa. The recent change in the JSE's listing requirements, which obligates companies to disclose their progress on board gender diversity on an annual basis, is a step in the right direction. Companies are encouraged to set realistic targets to gradually diversify their boards. To meet their targets, companies should increase efforts to identify promising female employees and to offer appropriate training and mentoring opportunities. Companies should also create more accommodating working environments which enjoy the support of male and female managers. Nomination committees should female candidates not only from within their organisations, but also from beyond their traditional networks. Unless companies voluntarily step up to the challenge, legislation is likely to follow.

Despite international evidence that shows that shareholder activists have an important role to play in changing board gender compositions, none of the asset managers in this study has engaged investee companies on the topic. In cases where no significant improvements in board gender diversity are noted, public voice strategies could be used to drive more rapid transformation.

By addressing gender stereotypes, career counselling teachers and other educators could initiate the cultural change called for by participants and diversity experts. If more attention is given to shareholders' rights and responsibilities in commerce curricula, the next generation of directors and investors might be more inclined to question and address the status quo.
Future studies could centre on the experiences of successful female directors. More research is also necessary on the effectiveness of mentoring and coaching programmes in diversifying the talent pipeline and assisting female directors to reach their full potential.

\section{Acknowledgments Competing interests}

The authors declare that they have no financial or personal relationship(s) which may have inappropriately influenced them in writing this article.

\section{Authors' contributions}

R.F. conducted the semi-structured personal interviews. S.V. and N.M-K. conceptualised the study and wrote the article.

\section{References}

Adams, R.B. \& Ferreira, D., 2009, 'Women in the boardroom and their impact on governance and performance', Journal of Financial Economics 94(2), 291-309. https://doi.org/10.1016/j.jfineco.2008.10.007

African Development Bank, 2015, 'Where are the women: Inclusive boardrooms in Africa's top listed companies', viewed 1 April 2016, from http://www.afdb.org/ fileadmin/uploads/afdb/Documents/Publications/Where are the Women Inclusive_Boardrooms_in_Africa\%E2\%80\%99s_top-listed_companies.pdf

Ahern, K.R. \& Dittmar, A.K., 2012, 'The changing of the boards: The impact on firm valuation of mandated female board representation', The Quarterly Journal of Economics 127(1), 137-197. https://doi.org/10.1093/qje/qjr049

Almazan, A., Hartzell, J.C. \& Starks, L., 2005, 'Active institutional shareholders and the cost of monitoring: Evidence from executive compensation', Financia Management Winter 34(4), 5-34. https://doi.org/10.1111/j.1755-053X.2005. tb00116.x

April, K., Dreyer, S. \& Blass, E., 2007, 'Gender impediments to the South African executive boardroom', South African Journal of Labour Relations 31(2), 51-67.

Australian Institute of Company Directors, 2016, 'Women on ASX 200 boards on the rise', viewed 30 May 2017, from http://aicd.companydirectors.com.au/advocacy/ board-diversity/women-on-asx-200-boards-on-the-rise

Bart, C. \& McQueen, G., 2013, 'Why women make better directors', International Journal of Business Governance and Ethics 8(1), 93-99. https://doi.org/10.1504/ IJBGE.2013.052743

Bauer, R., Moers, F. \& Viehs, M., 2015, 'Who withdraws shareholder proposals and does it matter? An analysis of sponsor identity and pay practices', Corporate Governance: An International Review 23(6), 472-488. https://doi.org/10.1111/ corg.12109

Bear, S., Rahman, N. \& Post, C., 2010, 'The impact of board diversity and gender composition on corporate social responsibility and firm reputation', Journal of Business Ethics 97(2), 207-221. https://doi.org/10.1007/s10551-010-0505-2

Becht, M., Franks, J., Mayer, C. \& Rossi, S., 2010, 'Returns to shareholder activism: Evidence from a clinical study of the Hermes UK Focus Fund', The Review of Financial Studies 23(3), 3093-3129. https://doi.org/10.1093/rfs/hhn054.ra

Bernardi, R.A. \& Threadgill, V.H., 2010, 'Women directors and corporate social responsibility', Electronic Journal of Business Ethics and Organization Studies 15(2), 15-21.

Bertrand, M., Black, S., Jensen, S. \& Lleras-Muney, A., 2014, Breaking the glass ceiling? The effect of board quotas on female labor market outcomes in Norway, National Bureau of Economic Research (NBER) Working Paper No. 20256, NBER, Cambridge, viewed 24 February 2017, from http://www.nber.org/papers/w20256.pdf

Bhana, N., 2010, 'The stock market reaction to criticism of corporate governance practices of companies listed on the JSE', Investment Analysts Journal 72, 1-12.

Bøhren, $\varnothing$. \& Staubo, S., 2014, 'Does mandatory gender balance work? Changing organizational form to avoid board upheaval', Journal of Corporate Finance 28, 152-168. https://doi.org/10.1016/j.jcorpfin.2013.12.005

Bonorchis, R., 2016, 'PIC attacks SA pay policies', Bloomberg, 8 April, viewed 8 April 2016, from http://www.iol.co.za/business/news/pic-attacks-sa-paypolicies-2006855

Businesswomen's Association of South Africa (BWA), 2013, Women empowerment and gender equality Bill/BWA report 2013, viewed 24 February 2017, from http:// bwasa.co.za/files/docs/0/52823da75a1e4 report_on the woman empowerment_and_gender_equality_bill.pdf

Businesswomen's Association of South Africa (BWA), 2015, 'Women in leadership census 2015', viewed 2 January 2016, from http://www.bwasa.co.za/news/bwawomen-in-leadership-census-media-release

Catalyst, 2014, 'Legislative board diversity', viewed 13 February 2017, from http:// www.catalyst.org/legislative-board-diversity 
Cha, Y., 2013, 'Overwork and the persistence of gender segregation in occupations', Gender and Society 27(2), 158-184. https://doi.org/10.1177/0891243212470510

Chamuka, T., 2011, 'The SADC gender protocol: Are the 2015 objectives achievable?', NGO Pulse, 17 August, viewed 12 February 2017, from http://www.ngopulse.org/ article/sadc-gender-protocol-are-2015-objectives-achievable

Chovwen, C., 2007, 'Barriers to acceptance, satisfaction and career growth Implications for career development and retention of women in selected male occupations in Nigeria', Women in Management Review 22(1), 68-78. https://doi. org/10.1108/09649420710726238

Clarke, T., 2017, International corporate governance: A comparative approach, Routledge, Oxon.

Commission for Gender Equality, 2017, Functions, viewed 8 February 2017, from http://www.cge.org.za/functions/

Davies, E.M., 2011, 'Women on boards', viewed 5 February 2017, from https://www. gov.uk/government/uploads/system/uploads/attachment_data/file/31480/11 745-women-on-boards.pdf

Davies, E.M., 2015, 'Improving the gender balance on British boards', viewed 5 February 2017, from https://www.gov.uk/government/uploads/system/uploads/ attachment_data/file/482059/BIS-15-585-women-on-boards-davies-review-5year-summary-october-2015.pdf

Deloitte, 2015, 'Diversity in the boardroom. Article 2. External pressures', viewed 25 May 2017, from https://www2.deloitte.com/content/dam/Deloitte/za/Documents/ governance-risk-compliance/ZA_Board_Diversity_2.PDF

Department of Trade and Industry, 2013, General notice: Broad-based black economic empowerment act (53/2003): Issue of codes of good practice, Government empowerment act (53/2003): Iss
Gazette, 580(36928), South Africa.

Department of Women, Children and People with Disabilities, 2015, South Africa's 5th periodic committee on the elimination of discrimination against women report, Government Gazette 602(39131), South Africa.

Du Plessis, J., O'Sullivan, J. \& Rentschler, R., 2014, 'Multiple layers of gender diversity on corporate boards: To force or not to force?', Deakin Law Review 19(1), 1-50. https://doi.org/10.21153/dlr2014vol19no1art207

Ensor, L., 2014, 'Withdrawal of gender equity bill welcomed', Business Day, 10 July, viewed 10 July 2014, from http://www.bdlive.co.za/business/2014/07/10/ withdrawal-of-gender-equity-bill-welcomed

Ernst \& Young, 2014, 'Women remain underrepresented in senior public sector leadership posts across G20 countries', viewed 15 February 2017, from http:// www.ey.com/sg/en/newsroom/news-releases/news-ey-women-remainunderrepresented-across-g20-countries

European Parliament News, 2015, 'Women on boards: MEPs urge ministers to agree position at last', European Parliament, viewed 13 February 2017, from http:// www.europarl.europa.eu/news/en/news-room/20151201IPR05555/women-onboards-meps-urge-ministers-to-agree-a-position-at-last

Fajardo, C. \& Erasmus, M., 2017, 'Gender (dis)parity in South Africa', Bain \& Company 24 May, viewed 25 May 2017, from http://www.bain.com/publications/articles/ gender-disparity-in-south-africa.aspx

Farrell, K.A. \& Hersch, P.L., 2005, 'Additions to corporate boards: The effect of gender', Journal of Corporate Finance 11(1-2), 85-106. https://doi.org/10.1016/j. jcorpfin.2003.12.001

Gantchev, N., 2013, 'The costs of shareholder activism: Evidence from a sequential decision model', Journal of Financial Economics 107(3), 610-631. https://doi. org/10.1016/j.jfineco.2012.09.007

Gillan, S. \& Starks, L., 2003, 'Corporate governance, corporate ownership, and the role of institutional investors: A global perspective', Journal of Applied Finance 13(2), 4-22. https://doi.org/10.2139/ssrn.439500

Gino, F. \& Brooks, A.W., 2015, 'Explaining gender differences at the top', Harvard Business Review, 23 September, viewed 14 February 2017, from https://hbr. org/2015/09/explaining-gender-differences-at-the-top

Glass, C., Cook, A. \& Ingersoll, A.R., 2015, 'Do women leaders promote sustainability? Analyzing the effect of corporate governance composition on environmental performance', Business Strategy and the Environment 25(7), 495-511. https://doi. performance', Business
org/10.1002/bse.1879

Goodman, J., Louche, C., Van Cranenburgh, K.C. \& Arenas, D., 2014, 'Social shareholder engagement: The dynamics of voice and exit', Journal of Business Ethics 125(2) 193-210. https://doi.org/10.1007/s10551-013-1890-0

Governance Metrics International (GMI) Ratings, 2014, 'Frequently asked questions', viewed 25 May 2017, from http://www.gmianalyst.com/_assets/GMIRatings_ GMIAFAQ.pdf

Gul, F.A., Hutchinson, M. \& Lai, K.M.Y., 2013, 'Gender-diverse boards and properties of analyst earnings forecasts', Accounting Horizons 27(3), 511-538. https://doi. org/10.2308/acch-50486

Harris, I.C. \& Shimizu, K., 2004, 'Too busy to serve? An examination of the influence of overboarded directors', Journal of Management Studies 41(5), 775-798. https:// doi.org/10.1111/j.1467-6486.2004.00453.x

Hasenfuss, M., 2016, 'Market watch: Golden silence', Financial Mail, 21 January viewed 21 January 2016, from http://www.financialmail.co.za/opinion/ columnists/2016/01/21/market-watch-golden-silence

Institute of Directors in Southern Africa (IoDSA), 2016a, King IV Report on corporate governance for South Africa, viewed 10 December 2017, from http://www.iodsa. co.za/?page=KingIV

Institute of Directors in Southern Africa (IODSA), 2016b, IODSA joins 30\% club in bid to improve SA board performance, viewed 1 August 2016, from http://www.iodsa. co.za/news/301287/.
Johannesburg Stock Exchange (JSE), 2015, 'Implementation of service issue 21: JSE listing requirements', viewed 15 February 2017, from https://www.jse.co.za/ content/JSEAnnouncementItems/JSE\%20Letter $\% 20$ Implementation $\% 20$ content/JSEAnnouncementltems/JSE $\% 2$ 20 Letter $\% 201 \mathrm{mpl}$
Service $\% 20$ Issue $\% 2021 \% 20-\% 20 \% 20$ November $\% 202015$.pdf

Johannesburg Stock Exchange (JSE), 2016, 'Amendments to the JSE listings requirements', Part 1 of 2016, 1 November, viewed 15 February 2017, from https://www.jse.co.za/content/JSEAnnouncementltems/20161101Explanatory\%20Memorandum\%20Part $\% 201 \% 20$ of $\% 202016$.pdf.

Johnson, Z. \& Mathur-Helm, B., 2011, 'Experiences with queen bees: A South African study exploring the reluctance of women executives to promote other women in the workplace', South African Journal of Business Management 42(4), 47-55.

Kamonjoh, E., 2014, Gender diversity on boards: A review of global trends, Institutional Shareholder Services, viewed 25 May 2017, from https://www.issgovernance. com/file/publications/2014-iss-global-board-diversity-report.pdf

Kelly, T., 2013, 'The ultimate male feminist? 5 things Nelson Mandela did for women', CNN, 8 December, viewed 3 January 2017, from http://edition.cnn.com/2013/ $12 / 08 /$ world/africa/the-ultimate-male-feminist-mandela/

Konrad, A.M., Kramer, V. \& Erkut, S., 2008, 'Critical mass: The impact on three or more women on corporate boards', Organisational Dynamics 37(2), 145-164. https:// doi.org/10.1016/j.orgdyn.2008.02.005

Kumra, S. \& Vinnicombe, S., 2008, 'A study of the promotion to partner process in a professional services firm: How women are disadvantaged', British Journal of Management 19(1), 65-74. https://doi.org/10.1111/j.1467-8551.2008.00572.x

La Porta, R., Lopez-de-Silanes, F., Shleifer, A. \& Vishny, R., 2000, 'Investor protection and corporate governance', Journal of Financial Economics 58(1-2), 3-27. https:// doi.org/10.1016/50304-405X(00)00065-9

Liebenberg, S., 2000, Human development and human rights: South African country study, Human Development Report 2000 Background Paper, viewed 9 February 2017, from http://hdr.undp.org/sites/default/files/sandra_liebenberg.pdf

Loop, P., 2016, 'Board composition and shareholder activism', PwC, May, viewed 8 September 2016, from https://www.pwc.com/us/en/governance-insights-center/ publications/assets/board-composition-and-shareholder-activism.pdf

Mabe, B., 2015, 50\% of women \& $2 \%$ of people with disabilities employment by departments: Department of Public Services and Administration monitoring report, Parliamentary Monitoring Group, viewed 12 February 2017, from https:// report, Parliamentary Monitoring Group,
pmg.org.za/committee-meeting/21298/

Mans-Kemp, N. \& Viviers, S., 2015, 'Investigating board diversity in South Africa', Journal of Economic and Financial Sciences 8(2), 392-414.

Marquardt, C. \& Wiedman, C., 2016, 'Can shareholder activism improve gender diversity on corporate boards?', Corporate Governance: An International Review 24(4), 443-461. https://doi.org/10.1111/corg.12170

Marthur-Helm, B., 2005, 'Equal opportunity and affirmative action for South African women: A benefit or barrier?', Women in Management Review 20(1), 56-71. https://doi.org/10.1108/09649420510579577

Martin, P. \& Barnard, A., 2013, 'The experience of women in male-dominated occupations: A constructivist grounded theory inquiry', SA Journal of Industria Psychology 39(2), 1-12.

Mavin, S., 2008, 'Queen bees, wannabees and afraid to bees: No more "best enemies" for women in management?', British Journal of Management 19(1), 75-84. https://doi.org/10.1111/j.1467-8551.2008.00573.x

McCahery, J.A., Sautner, Z. \& Starks, L.T., 2016, 'Behind the scenes: The corporate governance preferences of institutional investors', The Journal of Finance 71(6) 2905-2932. https://doi.org/10.1111/jofi.12393

Mdaka, Y., 2016, 'Shocking black drop-out rate in SA's universities', Destiny Man, 19 May, viewed 25 February 2017, from http://www.destinyman.com/2016/05/19/ black-university-drop-rate-horrific/

Natesan, P., 2013, South Africa is a leader in gender diversity on corporate boards, says new study, Institute of Directors Southern Africa, viewed 12 November 2016,
from http://www.iodsa.co.za/news/135560/South-Africa-is-a-Leader-in-Genderfrom http://www.iodsa.co.za/news/135560/South-Afric
Diversity-on-Corporate-Boards-says-New-Study.htm

Nordén, L. \& Strand, T., 2011, 'Shareholder activism among portfolio managers: Rational decision or 15 minutes of fame?', Journal of Management and Governance 15(3), 375-391. https://doi.org/10.1007/s10997-009-9114-9

Nyirenda, M., 2010, 'Board composition in companies listed on the Johannesburg Stock Exchange', master's dissertation, University of Pretoria.

Oliphant, P., 2015, 'South Africa falling short in gender equality standards', Mail \& Guardian, 4 May, viewed 12 February 2017, from http://mg.co.za/article/201505-04-south-africa-falling-short-in-gender-equality-standards

Organisation for Economic Co-operation and Development (OECD), 2012, Closing the gender gap: Act now, OECD, Paris.

Partnoy, F. \& Thomas, R., 2005, The new shareholder activism, Social Sciences Research Network, viewed 1 April 2006, from http://ssrn.com/abstract $=876344$

Perrault, E., 2015, 'Why does board gender diversity matter and how do we get there? The role of shareholder activism in deinstitutionalizing old boys' networks', Journal of Business Ethics 128(1), 149-165. https://doi.org/10.1007/s10551-0142092-0

PwC, 2016, 'The swinging pendulum: Board governance in the age of shareholder empowerment', viewed 25 May 2016, from https://www.pwc.com/us/en/ corporate-governance/annual-corporate-directors-survey/assets/pwc-2016annual-corporate--directors--survey.pdf

Rao, H., Morril, C. \& Zald, M.N., 2000, 'Power plays: How social movements and collective action create new organizational forms', Research in Organizational Behavior 22, 237-281. https://doi.org/10.1016/S0191-3085(00)22007-8 
Rehbein, K., Waddock, S. \& Graves, S.B., 2006, 'Understanding shareholder activism: Which corporations are targeted?', Business and Society 43(3), 239-267. https:// Which corporations are targeted?,

Ritter-Hayashi, D., Vermeulen, P. \& Knoben, J., 2016, Gender diversity and innovation: The role of women's economic opportunity in developing countries, Working paper, Institute of Management Research, Radboud University.

Robinson, G. \& Dechant, K., 1997, 'Building a business case for diversity', Academy of Management Executive 11(3), 21-31. https://doi.org/10.5465/ame.1997.9709 231661

Scholtz, A., 2014, 'Women empowerment \& gender equality bill: Are there claws in the clauses?', Business Brief, February/March, pp. 40-41.

Seierstad, C., 2016, 'Beyond the business case: The need for both utility and justice rationales for increasing the share of women on boards', Corporate Governance: An International Review 24(4), 390-405. https://doi.org/10.1111/corg.12117

Seierstad, C., Huse, M. \& Seres, S., 2015, 'Lessons from Norway in getting women onto corporate boards', The Conversation, 6 March, viewed 13 February 2017, from http://theconversation.com/lessons-from-norway-in-getting-women-ontohttp://theconversation
corporate-boards-38338

Seierstadt, C. \& Opsahl, T., 2011, 'For the few not the many? The effects of affirmative action on presence, prominence, and social capital of women directors in Norway',
Scandinavian Journal of Management 27(1), 44-54. https://doi.org/10.1016/j. scandinavian Journal

Simpson, W.G., Carter, D.A. \& D'Souza, F., 2010, 'What do we know about women on boards?', Journal of Applied Finance 20(2), 27-39.

Sorsa, P., 2016, Gender quotas for corporate boards - Do they work? Lessons from Norway, Organisation for Economic Co-operation and Development Ecoscope viewed 13 February 2017, from https://oecdecoscope.wordpress.com/2016/ 03/08/gender-quotas-for-corporate-boards-do-they-work-lessons-from-norway/

Steward, D., 2014, The women empowerment and gender equality bill, FW de Klerk Foundation, viewed 15 February 2017, from http://www.fwdeklerk.org/index.php/ en/latest/news/204-article-the-women-empowerment-and-gender-equality-bill

Terjesen, S., Aguilera, R.V. \& Lorenz, R., 2015, 'Legislating a woman's seat on the board: Institutional factors driving gender quotas for boards of directors', Journal of Business Ethics 128(2), 233-251. https://doi.org/10.1007/s10551 014-2083-1
Terjesen, S. \& Sealy, R., 2016, 'Board gender quotas: Exploring ethical tensions from a multi-theoretical perspective', Business Ethics Quarterly 26(1), 23-65. https://doi. org/10.1017/beq.2016.7

Terjesen, S., Sealy, R. \& Singh, V., 2009, 'Women directors on corporate boards: A review and research agenda', Corporate Governance: An International Review 17(3), 320-337. https://doi.org/10.1111/j.1467-8683.2009.00742.x

Thirty Percent Coalition, 2017, 'About', viewed 1 April 2017, from https:// www.30percentcoalition.org/

Tinsley, C.H., Wade, J.B., Main, B.G.M. \& O'Reilly, C.A., 2017, 'Gender diversity on U.S corporate boards: Are we running in place?', Industrial and Labor Relations Review 70(1), 160-189. https://doi.org/10.1177/0019793916668356

Torchia, M., Calabrò, A. \& Huse, M., 2011, 'Women directors on corporate boards: From tokenism to critical mass', Journal of Business Ethics 102(2), 299-317. https://doi.org/10.1007/s10551-011-0815-z

Vetten, L., 2016, 'Local elections 2016 show that South Africa's women continue to play second fiddle', Mail \& Guardian, 11 August, viewed 11 August 2016, from http://mg co za/article/2016-08-11-local-elections-2016-show-that-southhttp://mg.co.za/article/2016-08-11-local-e

Viviers, S. \& Smit, E.vdM., 2015, 'Institutional proxy voting in South Africa: Process, outcomes and impact', South African Journal of Business Management 46(3), 23-34.

Wang, M. \& Kelan, E., 2013, 'The gender quota and female leadership: Effects of the Norwegian gender quota on board chairs and CEOs', Journal of Business Ethics 117(3), 449-466. https://doi.org/10.1007/s10551-012-1546-5

Wiersema, M. \& Mors, M., 2016, 'What board directors really think of gender quotas', Harvard Business Review, viewed 13 February 2017, from https://hbr. org/2016/11/what-board-directors-really-think-of-gender-quotas

Willard, T., Carleton, W.T., Nelson, J.M. \& Weisbach, M.S., 2002, 'The influence of institutions on corporate governance through private negotiations: Evidence from TIAA-CREF', The Journal of Finance 53(4), 1335-1362.

Willey, K., 2017, “'Bringing Canadian women on board": A behavioural economics perspective on whether public reporting of gender diversity will alter the maledominated composition of Canadian public company boards and senio management', Canadian Journal of Women and the Law 29(1), 182-210. https:// doi.org/10.3138/cjwl.29.1.182 